\title{
Evaluating Teaching Methods Research Articles published in Iraqi Academic Journals
}

\author{
Majid Abdul-Mohammed Jassim, Asst.Prof. Dr. Muna M.A. Al-Khateeb \\ ${ }^{1}$ Ph.D Candidate in Teaching Methods, College of Basic Education/University of Babylon ,Email: altuleibawi 1970@gmail.com \\ ${ }^{2}$ Asst.Prof. Dr. in TEFL, College of Basic Education/University of Babylon, Email: munaalkhteeb2003@gmail.com
}

\section{ABSTRACT}

Teaching Methods research , which lies under the umbrella of educational research , has witnessed rapid development , however, very few if any have examined the quality of these articles .Therefore, This study aimed at evaluating Teaching Methods research articles published in Iraqi journals between 2015 and 2019 in the light of suggested evaluation criteria developed by the researcher. A descriptive-analytical approach was manipulated to achieve the goals of the study. The main tool the researcher used to collect data was a content analysis card. The researcher has benefited from related literature , journals , previous studies, and books to build the criteria of evaluation of his study tool. A total of 160 papers were examined to evaluate the components of research article. The study is considered to be important since it is a second to none in the specialization of Teaching Methods in Iraq. The findings of this study indicate that the total mean score of all categories and subcategories of the 160 articles increase overtly ; 6608 ( rating score ), 41.300 ( Mean ), 82.60 relative weight on the 5-point scale, which means that these articles strongly met the suggested evaluation criteria.

Keywords:

Teaching Methods, evaluation criteria, academic journals.

Article Received: 18 October 2020, Revised: 3 November 2020, Accepted: 24 December 2020

\section{Introduction}

\section{The Problem of the Study and its Significance}

For decades, education and teaching have been systematically investigated . Teaching Methods ( henceforth TMs) research , which lies under the umbrella of educational research has been increasing in amount at a very rapid pace" (Göktaş, H et al. ,2012) , which can be regarded in this sense as it is an important indicator of development level of educational system of a country (Gülmez \& Yavuz, 2016). Besides a variety of activities held in a field, TM research reveals the production and accumulation of knowledge in that field (Yilmaz \& Altıkurt, 2012). Concordantly TMs research reveals the level of knowledge in educational context and particularly research regarding instruction affects the teaching practice by leading the implications in the teaching institutions and forming the basis for educational reforms .

Inquiry into teaching has been tracked for basically three different purposes. First, scholars and researchers aim to understand better the processes involved, to develop the knowledge base of teaching, and to contribute to theoretical frameworks, which help to conceptualize teaching. Second, inquiry into teaching has also been pursued for the purposes of improving practice. This is particularly the case, for instance, in action research studies that generally follow a cycle, beginning with the identification of a practical problem or area of concern, followed by the gathering of evidence using various research methods, decisions about how to change practice, and then the gathering of further evidence to monitor the effects of the change .Third, inquiry is fundamental to professional preparation, and research methods may be employed by student teachers, for example, in helping to make sense of their observations of teaching and in developing their own practice .(Westwood, P. S. (2008).

Published TMs research is the distribution system by which academics and scholars acquire much of their understanding of today's teaching problems . In this critical communicative process, the need for sound research meaningful, interpretable information is imperative. Yet, considerable doubt has been raised as to the 
quality of Iraqi published TMs research articles since the citations of these articles are somehow low in spite of the increase in numbers of published articles ( Al Bahadli , 2018).

Published articles in Iraqi journals in TMs specialization have not undergone an accurate and formal scientific and statistical analysis showing their reality - according to the researchers knowledge. Many scholars and researchers interested in the field of TMs have done a lot of studies and this number continued to rise with increasing interest.

Although scientific published articles on TMs have the lion's share among other fields' published articles, very few, if any at all, evaluation studies have been conducted to evaluate them. Investigating the quality of TMs articles published in Iraqi journals is of vital significance for scholars and academics

Numerous guidelines for evaluating educational research have appeared in previous literature and studies . (Suydam,1968),( Creswell, 1994) (Research Council, 2002), (Gastel, 2002), Boote and Beile (2005) ( American Educational Research Association (AERA, 2006), (Pajares, 2007), (Nunn \& Adamson, 2007), (Schostak, 2008), , American Psychological Association (APA, 2008),( Johnson, 2008) (Fraenkel \& Wallen, 2009) European Association of Science Editors (EASE, ), and (Gottfried, Vosmik, \& Johnson, 2008), but none have appeared in Iraqi literature and studies .The study, therefore, aims at evaluate the components of the TM articles published in Iraqi academic journals. The study will answer the following question:

To what extent do the Components of the TMs articles published in Iraqi journals match to the criteria for high quality research writing?"

The value of this research stems from the fact that it is of vital significance in several areas in the TMs specification ; Scarcity of analytical research has been done to the Iraqi TM researches ;Therefore, this study seeks to develop a theoretical analytical framework for research in the TM specialization .It also Identifies the real quality of TM researches published in Iraqi journals Furthermore, the study is considered of vital significance due to the fact that it directs researchers and scholars to address a variety of issues that have not been addressed before

\subsection{The Aims of the Study}

The researcher sets two main aims in this study. First, to examine the research quality of TM journal articles published in Iraqi journals . Second, to develop a valid and reliable rubric for evaluating TM research quality that is closely aligned with the internationally established criteria for evaluating TM research .

\subsection{Limits of the Study}

Spatial and Time Limits: The content of 160 TMs scholarly articles published in ten Iraqi academic journals during the period 20152019were analyzed and evaluated.

\subsection{The Procedures of the Study}

The procedure of quantitative content analysis in the study followed the steps described in Neuendorf (2002) as cited in Zhao, J., et.al.. (2017) :

(a) deciding content to be examined (i.e., TMs journal articles ), (b) choosing and defining the variables to be examined (i.e., evaluation criteria for TMs research), (c) sampling the material to be analyzed (i.e., random sampling), (d) developing standardized categories and coding rubric (see the appendix), (e) training raters and conducting preliminary rater reliability check, (f) coding the material with final rater reliability check, and (g) analyzing the results

\section{Theoretical Literature}

\subsection{Research on Teaching Methods}

In his 1964 address to the Associated Organizations for Teacher Education, Nate Gage - known to many as the father of research on teaching - made an impassioned plea for research on and for teacher education (Gage, N. L. (1978) . He believed both research about effective teaching that could inform the content of teacher education (research for teacher education) and research about the results of different 
approaches to recruiting and preparing teachers that could inform how teachers are educated (research on teacher education). Gage's plea for investments in research for teacher education was heard. During the 1970s, when the National Institute of Education was in its heyday and education research received more federal funding than it ever has before or since, there was considerable effort devoted to understanding what kinds of teaching actions produced strong learning outcomes .

Shulman (1986: 8) argued that in reading the literature of research on teaching, it is clear that central questions are unasked. The emphasis is on how teachers manage their classrooms, organize activities, allocate time and turns, structure assignments, ascribe praise and blame, formulate the levels of their questions, plan lessons, and judge general student understanding . He said "What we miss are questions about the content of the lessons taught, the questions asked, and the explanations offered. From the perspectives of teacher development and teacher education, a host of questions arise. Where do teacher explanations come from? How do teachers decide what to teach, how to represent it, how to question students about it and how to deal with problems of misunderstanding?

Research on TMs has enabled substantial progress to be made in curriculum development and reform, educating slow learners, understanding the psychological traits of the physically challenged individuals and in adapting methods of instructions to the needs of individual learners. Research on teaching has rendered an imperative contribution in acquiring information regarding different cultures, norms and values. (ibid)

The TMs research is precise, objective, scientific and a systematic process of conducting investigations. TMs research not just involves viewing areas and conducting investigations, but it involves conducting analysis and investigations in a specific, accurate, methodical and an organized manner . (Eggleston, J. (1979)
As educational research, various steps involved in research on Teaching Methods are mentioned (Ebel R.L. (1969; Kaul L. (1984):

a. Identifying the Problem, d. Collecting the Data

b. Formulating Objectives and Hypothesis e. Analyzing and Interpreting the Data

c. Deciding the Method of Research

f. Writing a Report

\subsection{Previous Studies}

As far as research evaluation is concerned, a lot of work has been done in this field, but none has been done in the TMs research especially in Iraq .The purpose behind reviewing the studies is to find a basis for the present study and shed light on the nature of the problem under study in order to achieve the intended aim

The constant increase in the volume of educational research being published, and the increasing tendency of administrators to rely on research in formulating policy, raises the problem of how best to evaluate what is published. Evaluation is one of the largest problems of the empirical era of education, which is probably only just beginning . The evaluation and assessment of research quality is a very complex task. Due to the subjective nature of the task differences between fields or even among researchers within the same field, it is very difficult to develop a generally accepted research quality assessment tool (Brown, J. R. \& Ozgur ,C. ,2018).However, the researcher needs some guidelines for identifying "good research" that are independent of the journal's guidelines in a particular field, and which can be applied to all fields. In other words, the researcher is searching for some underlying principles that will help us to identify "good research." Intensive reading for the following studies help the researcher to develop a set of criteria and guidelines that will hopefully act as a focal point for further discussion and development.

The researcher reviewed thirty-six national and foreign studies. Some of those studies shared certain aspects and differ in others, among themselves as well as with the current study . 
Few empirical studies ( Wandt et.al. (1967); Anderson \& A. H. Kerr J. (1968 ); Hall ,B.W.\& Ward ,A.W. (1975); Hall, B. W., et.al. (1988); Mohammed ,Nabil Rafeeq (2017)) were conducted to evaluate educational research articles showed that these articles had many flaws, such as a lack of systematic and comprehensive literature reviews, absence of a standard research report format, inadequacy in research context description, a deficiency of a prescribed methodology for data collection and analysis, and no explanations of study limitations

. Despite outdatedness of some the literature sources, the researcher makes use of them in present study to achieve the goals he sets.

Numerous guidelines for evaluating educational research have appeared in the last 40 years, demonstrating the need for informed, critical evaluation of the material appearing as research ( (Burns N. (1989); Finlay, L. (1997); Lotter, Hennie,(2000) ; Gastel, B. (2002) ; Saiedian H.(2007) ;. Pyrczak , F\& Buzzeo , T ( 2018); Brown, J. R. \& Ozgur ,C. (2018); Costa AP, Minayo MCS.(2019) ). These studies aimed at providing some guidelines (and requirements) for writing a research paper. These guidelines were of vital importance for the researcher because they help him build his coding in evaluating TM research in the current study

The researcher may benefit from these studies in highlighting the similarities and differences related to their methodology, tools, samples, statistical treatments , findings and recommendations as follows :

As it is clear from reviewing the studies, few studies have been done on evaluating educational research and there is hardly any about TMs research, which will strengthen the rationale of conducting the current study and make a new scientific addition in the specialization of teaching methods that may help researchers and academics in further studies.

\section{Method}

\subsection{Research Design}

"A descriptive analytical method was used to conduct the study. This type of research is defined by Brown and Rodgers (2002:118) as "Any research that describes a setting of events in numerical terms" . Content Analysis was conducted to identify to what extent the components ; namely title, abstract , introduction , theoretical background, method, results and discussion, of the TMs articles published in Iraqi Journals match the suggested criteria of evaluation

3.2. Population and Sample of the study. Due to the fact that the population of educational journals are too difficult to access. The researcher purposely selected a sample of ten of Iraqi educational journals accessed from Iraqi Academic Scientific Journals (IASJ) see Table 1. 640 articles are the target population of scholarly TMs articles published in the Iraqi journals during the period from 2015 to 2019

The sample was formed by stratifying the population of articles $(\mathrm{N}=640)$ by journal, and drawing an $25 \%$ sample of articles at random within each stratum (journal), thereby creating a proportionate stratified random sample of 160 articles (see Table 1)

Table 1: Population and sample of TMs articles published in Iraqi journals

\begin{tabular}{|c|c|c|c|}
\hline \multirow{2}{*}{} & \multicolumn{2}{|c|}{ IRAQI JOURNALS } & \multicolumn{2}{c|}{ Number of Articles } \\
\cline { 3 - 4 } & & Population & $\begin{array}{c}\% \\
\text { Sample }\end{array}$ \\
\hline 1. & DIRASAT TARBAWIYA & 48 & 12 \\
\hline 2. & Journal of Al-Qadisiya in arts and educational science & 68 & 17 \\
\hline 3. & Journal of Research Diyala humanity & 68 & 17 \\
\hline 4. & Journal of The Iraqi University & 60 & 15 \\
\hline
\end{tabular}




\begin{tabular}{|c|c|c|c|}
\hline 5. & journal of the college of Basic education & 72 & 18 \\
\hline 5. & Journal of College of Education for Women & 75 & 19 \\
\hline 7. & $\begin{array}{c}\text { Basic Education College Magazine For Educational and } \\
\text { Humanities Sciences }\end{array}$ & 72 & 18 \\
\hline 8. & Journal of Misan Researches & 72 & 18 \\
\hline 9. & Journal Of Educational and Psychological Researches & 55 & 14 \\
\hline 10. & Journal of Surra Man Raa & 50 & 12 \\
\cline { 2 - 4 } & & 640 & 160 \\
\hline
\end{tabular}

\subsection{Instrumentation}

\subsubsection{The Coding Form}

Because all of the evaluation criteria for nonexperimental studies (i.e., title , abstract , introduction, literature review, and discussion) were included in the criteria for experimental studies, a solo coding form that contains all of the evaluation criteria for both types (see the appendix ) was created. The kinds that are applicable to experimental studies but not to none-experimental inquiries were coded as not applicable (N/A) in this study. The coding form in this study consists of the following categories: Title, Abstract , Introduction, literature review, Method, Results, and Discussion. The introduction is further divided into problem, significance, and theoretical framework. The subsections under literature review are coverage and synthesis. Method contains research design, sampling, instrumentation, data collection procedure, and data analysis. Findings are about the presentation of the results, and discussion includes results, discussion, limitations, and implications .

Determining the number of points on a rating scale is the key to the development of the coding form. Examining previous studies that evaluated the research quality of education research, the researcher chose a five-point scale (very good, good, average, weak, very weak) was used to capture the variation in the degree to which a criterion is met, representing five levels of quality :

The number of items suggested in the rating scale were 60 . The investigators added 11 items to the original rating scale, 8 that were suggested by jury members and 3 that arose from the researcher personal experience in research consumption.

The 71-item scale includes seven subscales: (A) Title (10 item), (B) abstract (10 items), (C) introduction (11 items), (D) literature (8 items), (E) Methods (20 items), (F) Results (2 items), and (G) Discussion (10 items)

In order to get the validity of analysis, the researcher consulted a group of specialists which included thirteen Ph.D. holders from different universities, many supervisors and some expert teachers from Education Directorates and modifications were done on the assisting criteria sentences to contain 71 criteria (See Appendix).

To examine the reliability of the content analysis card, the researcher asked for the cooperation of two colleagues to help analyze the study TMs articles. Fifteen articles were randomly selected and coded independently by two researchers. The main aim of this field trial was to test how consistently each researcher interpreted the coding categories so as to revise the rubric later on. . The two raters then read through the coding form together and discussed any questions about the coding categories and the discrepancies. When inconsistencies or ambiguities were found, the coding categories were modified to remedy those inconsistencies or ambiguities. Most of the coding categories were further divided into smaller and more specific ones, generating 71 subcategories from the original 60 that were tested in the first trial

A statistical test for this ratio was calculated for each of the five standards and then the researcher calculated the mean of the data of the two cards . Holsti formula was used to determine the 
reliability. The ratio of agreement between the first and the second analyst for TMs articles was $90.97 \%$, which forms a strong agreement between the researchers .

To ensure Reliability through Time , the analysis of 15 articles published in the Iraqi journals were repeated after three weeks .Using Holsti Equation . it was found that the ratio of agreement between the first and the second rating for TMs articles was $94.06 \%$, which forms a strong coefficient correlation

\section{Results and Discussion.}

To answer the main question of the study "To what extent do components of the TMs articles published in Iraqi Journals match to the suggested criteria for high quality research writing.?"

The rating score, mean score, standard deviations, the relative weight, and the level for each criteria were calculated see Table (2):

Table 2

\begin{tabular}{|c|c|c|c|c|c|c|c|c|}
\hline No & Components & 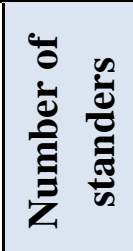 & 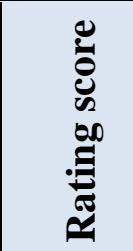 & Mean & SD & 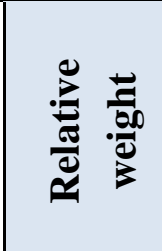 & 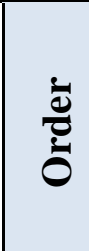 & Level \\
\hline 1 & Title & 10 & 7135 & 44.594 & 2.332 & $\% 89.19$ & 2 & Very good \\
\hline 2 & Abstract & 10 & 6608 & 41.300 & 2.933 & $\% 82.60$ & 5 & Good \\
\hline 3 & Introduction & 11 & 7825 & 48.906 & 6.631 & $\% 88.92$ & 3 & Very good \\
\hline 4 & $\begin{array}{l}\text { Theoretical } \\
\text { Literature }\end{array}$ & 8 & 3305 & 20.656 & 3.082 & $\% 51.63$ & 7 & Acceptable \\
\hline 5 & Method & 20 & 13201 & 82.506 & 18.236 & $\% 82.51$ & 6 & Good \\
\hline 6 & Results & 2 & 1469 & 9.181 & 0.970 & $\% 91.82$ & 1 & Very good \\
\hline \multirow[t]{2}{*}{7} & Discussion & 10 & 7104 & 44.400 & 4.826 & $\% 88.80$ & 4 & Very good \\
\hline & Total & 71 & 46647 & 291.543 & 35.636 & $\% 82.21$ & & Good \\
\hline
\end{tabular}

It is clear from the table ( 2 ) that:

1.The (results) component was ranked first with relative weight $(91.82 \%)$, which is at a very good level, and the researcher attributes that to fact that this component is in line with the suggested criteria of high quality research ( see the appendix ), where the two standards $(1,2)$, have rating score (1469) , mean (9.181), $\mathrm{SD}(0.970)$ and relative weight 91.82 .Therefore, results section has a very good level ( see the table 2),

This reflects the commitments of Iraqi scholars in presenting results of their research effectively and reporting complete results with sufficient and appropriate amount of data. Throughout his analysis of Iraqi TMs articles, the researcher traced how findings and results were relevant to the research questions or hypotheses .

2. The (Title ) component was ranked second with relative weight $(89.19 \%)$, which is at a very good level. The overall rating score of the title is (7135), the mean ( 44.594) and SD (2.332) See table 2 .The researcher attributes that to the wide experience of Iraqi scholars and academics have gained from their reviewing many previous studies and communicating with scholars from different countries online This increases their vocabulary, enabling them to choose the appropriate title for their researches. Evaluating 
the title section of Iraqi TMs articles, the researcher found that it matches to the suggested standards of a high quality research, where Standards $(2,3,5,9)$ have achieved a good level, and the standards $((1,4,6,7,8,10)$ have a very good level . ( for the suggested standards , see the appendix )

3.The (introduction) component was ranked third with relative weight $(88.92 \%)$, which is at a very good level .The overall rating score of the introduction is (7825), the mean (48.906), SD (6.631) see Table 2 . The researcher attributes this to the well-organized introduction involved in the Iraqi TMs articles . Introduction section was coped with the standards the researcher developed in the study, where the standards $(8,10,11)$, they are at a good level, and the standards $(1,2,3,4,5,6,7,9)$ have a very good level. ( for the suggested standards, see the appendix )

4.The (discussion) component was ranked fourth with relative weight $(88.80 \%)$, which is at a very good level and the researcher attributes that to the fact most research articles published in Iraqi TMs journals go in line with the 10 suggested standards, where the standards $(4,8,10)$ have attained a good level and the standards $(1,2,3,5,6,7,9)$ have a very good level ( for the suggested standards, see the appendix ). The overall rating score of the Discussion is (7104), the mean (44.400) and SD ( 4.826) See Table 2. This high ranking is due to the concisely presentation of discussion ; it does not exceed 1,500 words including citations. and it includes a brief statement of the principal findings, a discussion of the validity of the observations, a discussion of the findings in light of other published work dealing with the same or closely related subjects, and a statement of the possible significance of the work. Discussion section interprets the findings and explains patterns in and the relations among variables with evidence and concrete examples, explains how claims and interpretation address the research problem/issue, explains how claims and interpretations address research questions relates the findings/arguments to the broader problem in the field, indicates unsolved problems, notes the weaknesses of the study, emphasizes implications for theory draws implications for practice and discusses implications for (further) research

5.The component (abstract) was ranked fifth with relative weight $(82.60 \%)$, which is of a good level, and the researcher attributes that to the fact that all 10 suggested standards attain a very good level in the TMs articles published in the Iraqi journals. The overall rating score of the extract section is (6608), the mean ( 41.300) and SD ( 2.933) See Table 2. the standards (2,7 $, 8,10)$ have attained a very good level and the standards $(1,3,4,5,6.9)$ have a good level (for the suggested standards, see the appendix ) .The researchers follow a systematic way in including all necessary details of the study that capture a reader's interest and summarize the text. Abstracts in Iraqi articles follow core aspects such as reason for conducting the research , theme, purpose, Problem, brief background, methods and outcomes. The researchers determine skillfully how work done being added to the body of knowledge on the topic.

6 .The (Methodology) component was ranked sixth with relative weight $(82.51 \%)$, and it is at a good level ; The overall rating score of the methodology is (13201), the mean ( 82.506 ) and SD ( 18.236) See table 2 .The researcher attributes that to the good presentation of methodology .In this section, research writers articulate its appropriateness: how research design/method relate to research questions or hypothesis, provide information about samples sufficient for the study, note eligibility and exclusion criterion or special arrangements. This section matches to the suggested standards of a high quality research ; the standards $(5,6,9,10,11,12,13,14,15,18,19,20)$ attained a good level ; whereas the standard (16) had an average level, and the standards $(1,2,3,4,7,8,17)$ attained a very good level, ( for the suggested standards, see the appendix )

7.The (theoretical literature) component was ranked seventh with relative weight $(51.63 \%)$, and 
it is at an acceptable level. The overall rating score of the Theoretical framework section is (3305), the mean ( 20.656 )and SD ( 3.082) See Table 4 and the researcher attributes this decreasing level to the lack of comprehensive description literature review ; it does not cover the required reviews of the previous studies and does not justify criteria for inclusion and exclusion from review. Standards $(4,5,6)$ have attained an acceptable level, and the standards $(1,2,37,8)$ have an average level. , ( for the suggested standards, see the appendix )

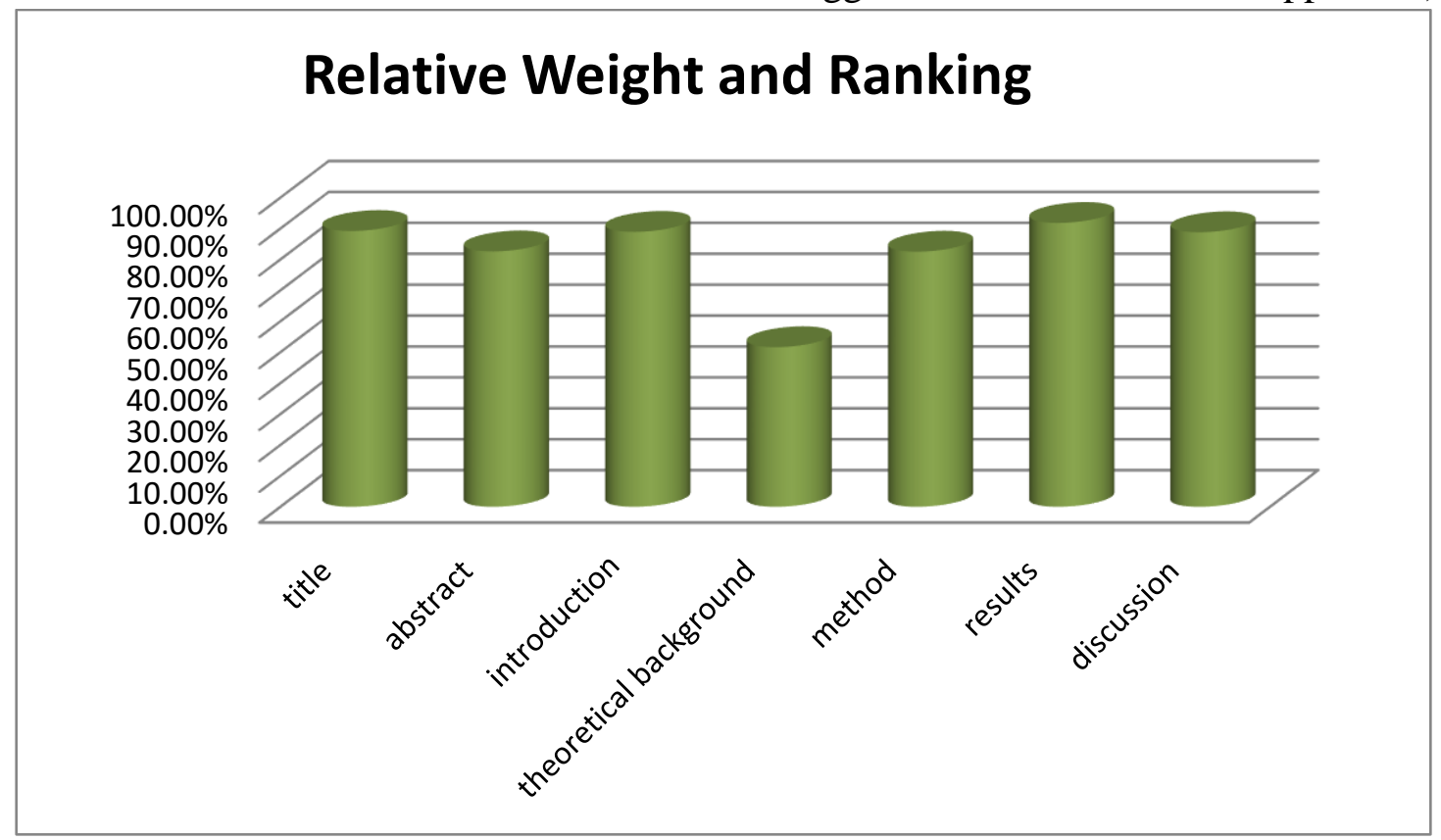

Diagram 1: Ranking and Relative Weight of TMs article Components

\section{Interpretation of the Results}

The findings of this study indicate that the overall mean score rise across categories and subcategories of the 160 articles was 6608 ( rating score ), 41.300 ( Mean ), 82.60 relative weight on the 5-point scale, which means that these articles strongly met the standards. The relative weight of the seven main sections ranged from $51.63 \%$ for theoretical literature to $\% 91.82$ for the results see (Table 2 and diagram 1 ) These relative weight values suggest that the results section appears to be relatively strong compared to the other sections but still the other sections are strong too. The overall components of TMs articles published in Iraqi journals obtained a relative weight $(82.21 \%)$, and they are of a good level, and the researcher attributes this to the wide writing experience that Iraqi scholars and writers have gained from communicating with universities, educational institutions and research centers as well as the increase in the number of Iraqi research .( Al Bahadli (2018)
Encouraging Iraqi scholars to publish in high impact factor journals in order for them to reach an international academic community and encouraging faculty members to write joint research and participate in scientific conference have an effective role in improving the reality of TMs articles. This and others are considered important reasons behind the improvement and upgrading of the TMs articles (ibid).

Moreover, These findings show that Iraqi TMs articles usually follow a prescribed methodology of data collection and analysis. Such research practices go in line with modern research ethics that are concerned with systematic procedures in knowledge production (Appadurai, 2000). It is thus very likely for such articles to be accepted or recognized by scholars outside Iraq if they are published in sober journals .

Despite the reality of scientific research in Iraq, which is limited and modest, as Iraq ranks late at the global level according to the indicators used to measure the progress of countries in the field of 
scientific research, such as spending on scientific research, the number of patents and scientific publication, the current study has proven the quality of Iraqi research in terms of the sobriety of the content (UNESCO, (2015)

The invisibility of Iraqi research articles in high impact factors journals might be not due to the weaknesses in writing them but due to technical and logistical variables. Many manuscripts are rejected to be published in high impact factor journals for some reasons such as : Stout, D.

Eet.al. (2006).

1.The manuscript is out of scope of the journal

2.The quality of writing is below publishable standards

3. The manuscript is not formatted correctly

4. The guidelines have not been followed

5. Language, writing and spelling issues

\subsection{Implications of the Study}

The findings of our study have a number of important implications for TMs research and publication practice in Iraq and potentially other emerging countries that are experiencing similar problems. First, Iraqi education researchers can improve the global visibility of their research and publication by publishing in international high impact factor journals . Second, Iraqi researchers should increase their telecommunications with other scholars in other countries for the sake of interchanging experience in writing research .Third, the Iraqi scholars and academic should make use of the suggested standards of a high quality research in conducting their researches .

\section{References}

[1] Anderson \& A. H. Kerr J. (1968) A Checklist For Evaluating Education Research, Educational Research, 11:1, 7475

[2] Appadurai, A. (2000). Grassroots globalization and the research imagination. In A. Appadurai (Ed.), Globalization (pp. 1-21). Durham, NC: Duke University Press.

[3] Bataineih, A. N. (2009). An Evaluation of the Authentic Socio Cultural Elements in the Prescribed English Language Textbooks of the Secondary Schools in Jordan. An-Najah Univiversity Journal. 23, (330-352)

[4] Boykin, L. (1972). Why Research in Education? Retrieved December 20, 2020 from

[5] http://www.ascd.org/ASCD/pdf/journals/e d_lead/el_197204_boykin.pdf

[6] Bryman, A. (2012). Social research methods. (4th edition). New York: Oxford University Press.

[7] Brown, J. and Rodgers, T. (2002). Doing Second Language Research. Oxford: Oxford University Press.

[8] Brown, J. R., \& Ozgur, C. (2018 ) Assessment of Research Quality. Retrieved December 20, 2020 from https://www.researchgate.net/publication/3 23203065

[9] Burns, N. (1989). Standards for Qualitative Research. Nursing Science Quarterly, 2(1), 44-52.

[10] Cicchetti, D. (2001). The precision of reliability and validity estimates re-visited:

[11] Distinguishing between clinical and statistical significance of sample size requirements. Journal of Clinical and Experimental Neuropsychology, 23, 695700.

[12] Costa, A. P., \& Minayo, M. C. D. S. (2019). Building criteria to evaluate qualitative research papers: a tool for peer reviewers. Revista da Escola de Enfermagem da USP, 53.

[13] Ebel R.L. (1969), =Encyclopedia of Educational Research,' London, The Macmillan Co

[14] Finlay, L. (1997). Evaluating Research Articles. British Journal of Occupational Therapy, 60(5), 205-208. https://doi.org/10.1177/030802269706000 504

[15] Gage, N. L. (1978). The scientific basis of the art of teaching. Teachers Coll Press. 
[16] Gastel, B. (2002). Guide published for peer reviewers of research manuscripts. Science Editor, 25, 46-48.

[17] Göktaş, Y., Hasançebi, F., Varışoğlu, B., Akçay, A., Bayrak, N., Baran, M., \& Sözbilir M. (2012). [Trends in Educational Research in Turkey: A Content Analysis]. Kuram ve Uygulamada Eğitim Bilimleri. 12 (1), 443-460

[18] Gülmez, D. \& Yavuz, M. (2016). [The evaluation of the articles related with educational leadership and administration published in 2012 in terms of aim and method]. Elementary Education Online, 15 (2.329-318)

[19] Guba, E. G., \& Lincoln, Y. S. (1994). Competing paradigms in qualitative research. In N. K. Denzin \& Y. S. Lincoln (Eds.), Handbook of qualitative research (pp. 105- 117). Thousand Oaks, CA: Sage

[20] Hall ,B.W.\& Ward ,A.W. (1975) , an evaluation study of educational research articles published during 1971, American Educational Research Journal Spring, Vol 12, No. 2, Pp. 109-128

[21] Hall, B. W., Ward, A. W., \& Comer, C. B. (1988). Published educational research: An empirical study of its quality. The Journal of Educational Research, 81(3), 182-189.

[22] Howe, K. R. (2009). Positivist dogmas, rhetoric, and education science question. Educational Researcher, 38, 428-440.

[23] Kaul L. (1984), =Methodology of Educational Research,' New Delhi, Vikas Publishing House

[24] Landis, J. R., \& Koch, G. G. (1977). The measurement of observer agreement for categorical data. Biometrics, 33, 159-174. doi: $10.2307 / 2529310$

[25] Lotter,Hennie,(2000),How to judge scientific Research Articles .SA Journal for Language Teaching

[26] Mackey, G. (2005). ESL textbook evaluation checklist. The Reading Matrix.
[27] Neuman, W. (1997). Social research methods: qualitative and quantitative approaches. MA: Allyn \& Bacon.

[28] Pyrczak, F., \& Tcherni-Buzzeo, M. (2018). Evaluating research in academic journals: A practical guide to realistic evaluation. Routledge.

[29] Saiedian ,H.(2007) Guidelines and Requirements for Writing a Research Paper https://www.academia.edu/18235953

[30] Selçuk, Z., Palancı, M., Kandemir, M. \& Dündar, H. (2014). [Tendencies of researches published in education and science journal: Content analysis]. Eğitim ve Bilim, 39 (173), 430-453

[31] Shulman, L. S. (1986). Those who understand: Knowledge growth in teaching. Educational researcher, 15(2), 814

[32] Stout, D. E., Rebele, J. E., \& Howard, T. P. (2006). Reasons research papers are rejected at accounting education journals. Issues in Accounting Education, 21(2), 8198.

[33] UNESCO, (2015) Review of Scientific Research in Iraq , 4 (56-119)

[34] Wandt, E., Adams, G. W., Collett, D. M., Michael, W. B., Ryans, D. G., \& Shay, C. B. (1967). An evaluation of educational research published in journals. Unpublished manuscript, Committee on Evaluation of Research, American Education Research Association.

[35] Westwood, P. S. (2008). What teachers need to know about teaching methods. Aust Council for Ed Research.

[36] White, M. D. and Marsh, E. E. (2006). Content analysis: A flexible methodology. Library Trends, 55(1), 22-45.

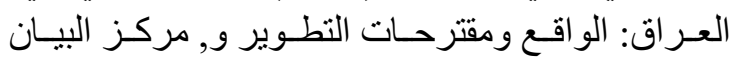
للار اسات و التخطيط

2.محمد , نبيل رفيق. (2017). تقويم بحوث المشرفين التربويين و الاختصاصبين الجدد (در اسة تحليلية). مجلـة

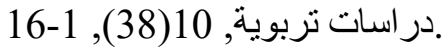




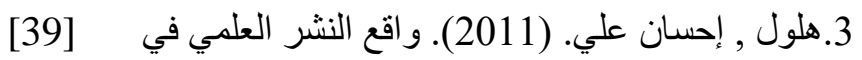

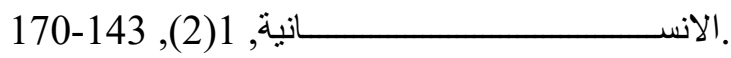
جامعة بابل: در اسة تقويمية. مجلة مركز بابل للار اسـات 
Appendix

\begin{tabular}{|c|c|c|c|c|c|c|c|c|}
\hline Sections & Categories & Subcategories & $\begin{array}{l}\text { Very } \\
\text { good } \\
5\end{array}$ & $\begin{array}{c}\text { Good } \\
4\end{array}$ & $\begin{array}{c}\text { average } \\
3\end{array}$ & $\begin{array}{c}\text { weak } \\
2\end{array}$ & Very weak 1 & N/A \\
\hline \multirow[t]{4}{*}{ Title } & Topic & $\begin{array}{l}\text { 1.describes the topic directly } \\
\text { 2.be new, innovative and attract the readers' } \\
\text { attention } \\
\text { 3.contain key words that draws the attention of } \\
\text { researchers' and international indexes } \\
\text { 4.be within a maximum of approximately } 15 \text { words } \\
\text { 5.Devoid of words that can be deleted } \\
\text { 6.Devoid of jargon, not standards abbreviations }\end{array}$ & & & & & & \\
\hline & Purpose & $\begin{array}{l}\text { 7.Be specific and disclosed about the purpose of the } \\
\text { research }\end{array}$ & & & & & & \\
\hline & Problem & 8.Determine the exact problem field & & & & & & \\
\hline & method & $\begin{array}{l}\text { 9.Describes the method, or methodology } \\
\text { 10.State the sample }\end{array}$ & & & & & & \\
\hline \multirow[t]{4}{*}{ Abstract } & Theme & $\begin{array}{l}1 \text { start with a brief theme sentence to orientate the } \\
\text { reader about the overall issue presented in the } \\
\text { article }\end{array}$ & & & & & & \\
\hline & Purpose & 2. indicate the main aim or purpose of the study & & & & & & \\
\hline & Problem & $\begin{array}{l}\text { 3. Summarize the problem } \\
\text { 4. explain clearly the academic and /or practical } \\
\text { importance of the study }\end{array}$ & & & & & & \\
\hline & Background & 5.State the background briefly & & & & & & \\
\hline
\end{tabular}




\begin{tabular}{|c|c|c|c|c|c|c|c|c|}
\hline & Method & 6.State the methods or methodology & & & & & & \\
\hline & Results & 7.State the results and conclusion & & & & & & \\
\hline & & $\begin{array}{l}\text { 8.Be within the required length (200-250) word } \\
\text { approx. } \\
\text { 9.devoid of references, drawings, tables, jargon or } \\
\text { incomprehensible abbreviations } \\
\text { 10.have accurate information and not exaggerate } \\
\text { more information than what stated in the research }\end{array}$ & & & & & & \\
\hline Sections & Categories & Subcategories & $\begin{array}{c}\text { Excelle } \\
\text { nt } \\
5\end{array}$ & $\begin{array}{c}\text { Good } \\
4\end{array}$ & $\begin{array}{c}\text { Mediocre } \\
3\end{array}$ & $\begin{array}{c}\text { Poor } \\
2\end{array}$ & $\begin{array}{c}\text { Completely } \\
\text { incompetent } \\
1\end{array}$ & N/A \\
\hline Introduction & $\begin{array}{l}\text { Problem } \\
\text { statement }\end{array}$ & $\begin{array}{l}\text { 1.Poses a statement of the problem clearly } \\
\text { 2. Describes a research gap } \\
\text { 3. Supports with rationale } \\
\text { 4.Hypotheses are clearly stated }\end{array}$ & & & & & & \\
\hline & $\begin{array}{l}\text { Purpose } \\
\text { Significance }\end{array}$ & $\begin{array}{l}\text { 5.Explains the purpose of the study } \\
\text { 6. States research questions (for qualitative study) or } \\
\text { hypothesis that includes variables going to be } \\
\text { measured and studied (for quantitative) } \\
\text { 7.Demonstrates theoretical importance of study } \\
\text { 8.Shows practical importance } \\
\text { 9. suggests originality, applicability, and interest to } \\
\text { the field }\end{array}$ & & & & & & \\
\hline & $\begin{array}{l}\text { Theoretical } \\
\text { framework }\end{array}$ & $\begin{array}{l}\text { 10."Describes conceptual or theoretical framework } \\
\text { used in the study" } \\
\text { 11.Justifies the conceptual or theoretical } \\
\text { framework }\end{array}$ & & & & & & \\
\hline
\end{tabular}




\begin{tabular}{|c|c|c|c|c|c|c|c|c|}
\hline \multirow[t]{2}{*}{$\begin{array}{l}\text { Literature } \\
\text { review }\end{array}$} & Coverage & $\begin{array}{l}\text { 1.Literature review is relevant } \\
\text { 2.Literature review is comprehensive } \\
\text { 3.Has justified criteria for inclusion and exclusion } \\
\text { from review }\end{array}$ & & & & & & \\
\hline & Synthesis & $\begin{array}{l}\text { 4.Identifies main ideas, perspectives (theories), or } \\
\text { methodologies used in the } \\
\text { Field } \\
\text { 5.Critically examines their advantages or } \\
\text { disadvantages } \\
\text { 6.Distinguishes what has been done to what needs } \\
\text { to be done } \\
\text { 7.Explains relations with previous studies by } \\
\text { demonstrating how the current } \\
\text { research joins and advances or challenges the } \\
\text { existing literature } \\
\text { 8.Integrates and synthesizes the review to tie into } \\
\text { the issues being investigated in } \\
\text { the current study }\end{array}$ & & & & & & \\
\hline Sections & Categories & $\begin{array}{l}\text { Subcategories } \\
\end{array}$ & $\begin{array}{c}\text { Excelle } \\
\text { nt } \\
5 \\
\end{array}$ & $\begin{array}{c}\text { Good } \\
4\end{array}$ & $\begin{array}{c}\text { Mediocre } \\
3\end{array}$ & $\begin{array}{c}\text { Poor } \\
2\end{array}$ & $\begin{array}{c}\text { Completely } \\
\text { incompetent } \\
1 \\
\end{array}$ & N/A \\
\hline Method & $\begin{array}{l}\text { Research } \\
\text { design and } \\
\text { method } \\
\text { theory } \\
\text { Sampling/par } \\
\text { ticipants }\end{array}$ & $\begin{array}{l}\text { 1.Describes types of research design, method, or } \\
\text { methodology } \\
\text { 2.Articulates its appropriateness: how research } \\
\text { design/method relate to research questions or } \\
\text { hypothesis } \\
\text { 3.Provides information about participants or } \\
\text { samples sufficient for the purpose of } \\
\text { the study } \\
\text { 4. Notes eligibility and exclusion criterion or special } \\
\text { arrangements }\end{array}$ & & & & & & \\
\hline
\end{tabular}




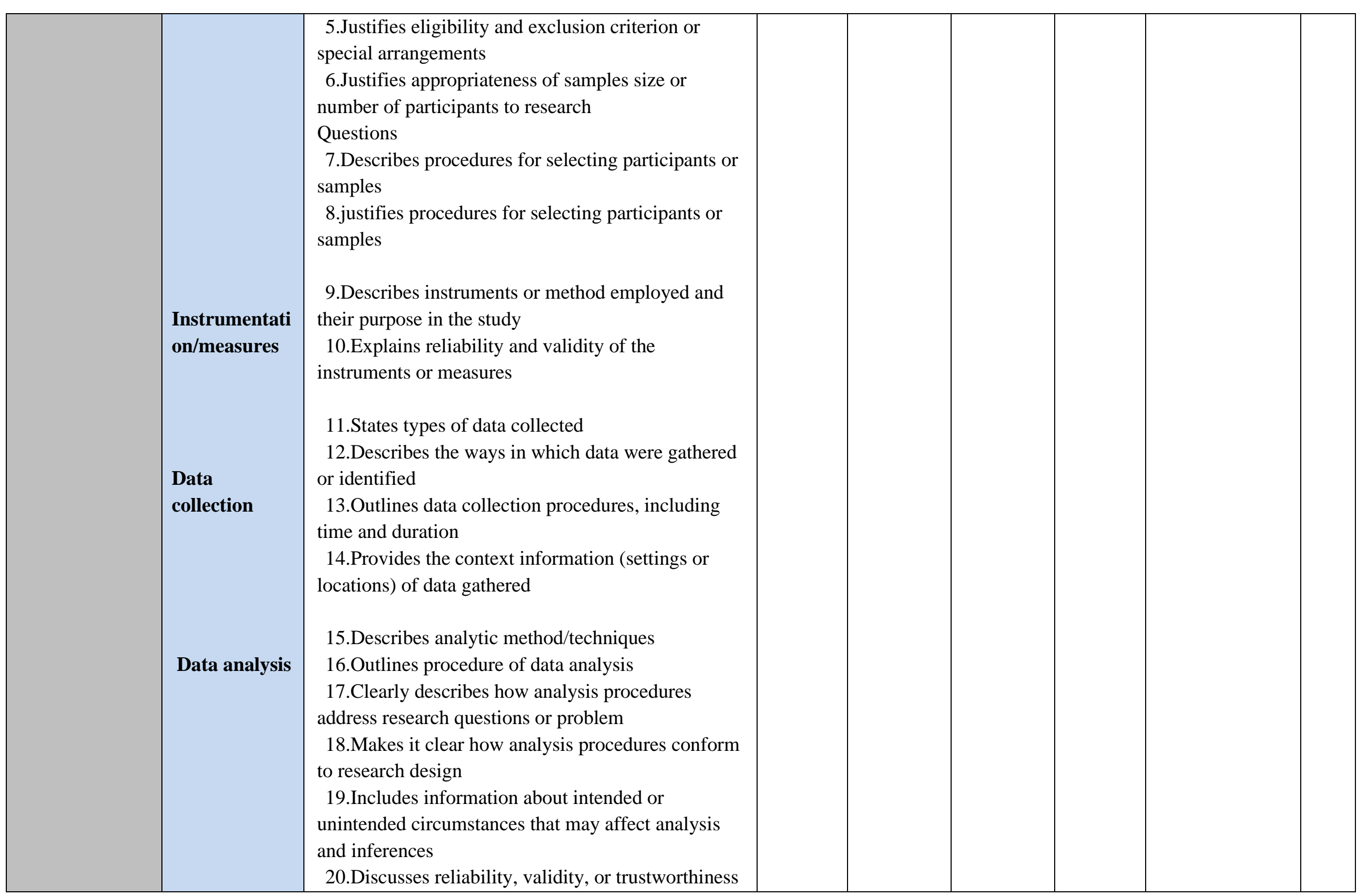




\begin{tabular}{|c|c|c|c|c|c|c|c|c|}
\hline & & $\begin{array}{l}\text { (e.g., potential sources of bias and the effects due to } \\
\text { data treatment) }\end{array}$ & & & & & & \\
\hline Sections & Categories & Subcategories & $\begin{array}{c}\text { Excelle } \\
\text { nt } \\
5\end{array}$ & $\begin{array}{c}\text { Good } \\
4\end{array}$ & $\begin{array}{c}\text { Mediocre } \\
3\end{array}$ & $\begin{array}{c}\text { Poor } \\
2\end{array}$ & $\begin{array}{c}\text { Completely } \\
\text { incompetent } \\
1\end{array}$ & N/A \\
\hline Results & $\begin{array}{l}\text { Results } \\
\text { /findings }\end{array}$ & $\begin{array}{l}\text { 1.Presents results effectively (reports complete } \\
\text { results with sufficient and appropriate amount of data } \\
\text { presented) } \\
\text { 2.Describes findings/results pertinent to each } \\
\text { research hypothesis or question }\end{array}$ & & & & & & \\
\hline
\end{tabular}




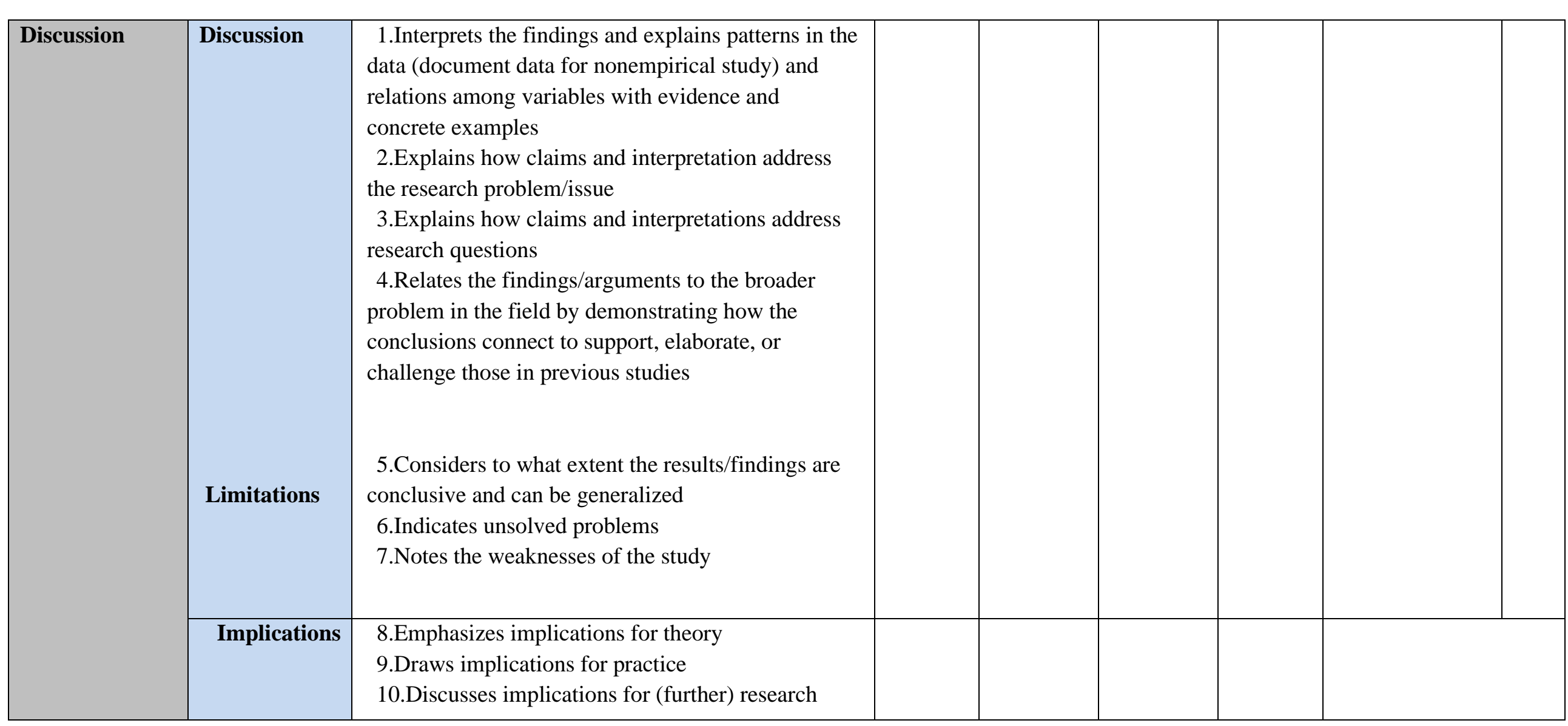

